\title{
An eco-epidemiological model with general functional response of predator to prey
}

\author{
Lopo de Jesus ${ }^{1}$, César Silva ${ }^{1}$, and Helder Vilarinho ${ }^{1}$ \\ ${ }^{1}$ University of Beira Interior
}

November 23, 2021

\begin{abstract}
We consider a nonautonomous eco-epidemiological model with general functions for predation on infected and uninfected preys as well as general functions associated to the vital dynamics of the susceptible prey and predator populations. We obtain persistence and extinction results for the infected prey based on assumptions on auxiliary systems constructed from the diseasefree system. We moreover consider an iterative process that can improve the extinction results. We apply our results to general eco-epidemiological models that include several examples existent in the literature.
\end{abstract}

\section{Hosted file}

JSV-ecoepidemiological-nonautonomous-2021-MMAS.pdf available at https://authorea.com/users/ 447571/articles/546534-an-eco-epidemiological-model-with-general-functional-response-ofpredator-to-prey

\section{Hosted file}

JSV-ecoepidemiological-nonautonomous-2021-MMAS.tex available at https://authorea.com/users/ 447571/articles/546534-an-eco-epidemiological-model-with-general-functional-response-ofpredator-to-prey 
figures/artigo-exe1-EXT-I/artigo-exe1-EXT-I-eps-converted-to.pdf 
figures/artigo-exe1-EXT-P/artigo-exe1-EXT-P-eps-converted-to.pdf 
figures/artigo-exe1-EXT-S/artigo-exe1-EXT-S-eps-converted-to.pdf 
figures/artigo-exe1-PERS-I/artigo-exe1-PERS-I-eps-converted-to.pdf 
figures/artigo-exe1-PERS-P/artigo-exe1-PERS-P-eps-converted-to.pdf 
figures/artigo-exe1-PERS-S/artigo-exe1-PERS-S-eps-converted-to.pdf 
figures/artigo-exe2-EXT-I/artigo-exe2-EXT-I-eps-converted-to.pdf 
figures/artigo-exe2-EXT-P/artigo-exe2-EXT-P-eps-converted-to.pdf 
figures/artigo-exe2-EXT-S/artigo-exe2-EXT-S-eps-converted-to.pdf 
figures/artigo-exe2-PERS-I/artigo-exe2-PERS-I-eps-converted-to.pdf 
figures/artigo-exe2-PERS-P/artigo-exe2-PERS-P-eps-converted-to.pdf 
figures/artigo-exe2-PERS-S/artigo-exe2-PERS-S-eps-converted-to.pdf 
figures/artigo-exe3-EXT-I/artigo-exe3-EXT-I-eps-converted-to.pdf 
figures/artigo-exe3-EXT-P/artigo-exe3-EXT-P-eps-converted-to.pdf 
figures/artigo-exe3-EXT-S/artigo-exe3-EXT-S-eps-converted-to.pdf 
figures/artigo-exe3-PERS-I/artigo-exe3-PERS-I-eps-converted-to.pdf 
figures/artigo-exe3-PERS-P/artigo-exe3-PERS-P-eps-converted-to.pdf 
figures/artigo-exe3-PERS-S/artigo-exe3-PERS-S-eps-converted-to.pdf 
figures/artigo-exe4-EXT-I/artigo-exe4-EXT-I-eps-converted-to.pdf 
figures/artigo-exe4-EXT-P/artigo-exe4-EXT-P-eps-converted-to.pdf 
figures/artigo-exe4-EXT-S/artigo-exe4-EXT-S-eps-converted-to.pdf 
figures/artigo-exe4-PERS-I/artigo-exe4-PERS-I-eps-converted-to.pdf 
figures/artigo-exe4-PERS-P/artigo-exe4-PERS-P-eps-converted-to.pdf 
figures/artigo-exe4-PERS-S/artigo-exe4-PERS-S-eps-converted-to.pdf 
figures/iteracao-etabeta/iteracao-etabeta-eps-converted-to.pdf 
figures/iteracao-lambdabeta/iteracao-lambdabeta-eps-converted-to.pdf 